\title{
Binding Kinetics of ZM241385 Derivatives at the Human Adenosine $\mathrm{A}_{2 \mathrm{~A}}$ Receptor
}

\author{
Dong Guo, Lizi Xia, Jacobus P. D. van Veldhoven, Marc Hazeu, Tamara Mocking, \\ Johannes Brussee, Adriaan P. IJzerman, and Laura H. Heitman*[a]
}

Classical drug design and development rely mostly on affinityor potency-driven structure-activity relationships (SAR). Thus far, a given compound's binding kinetics have been largely ignored, the importance of which is now being increasingly recognized. In the present study, we performed an extensive structure-kinetics relationship (SKR) study in addition to a traditional SAR analysis at the adenosine $A_{2 A}$ receptor $\left(A_{2 A} R\right)$. The ensemble of $24 A_{2 A} R$ compounds, all triazolotriazine derivatives resembling the prototypic antagonist ZM241385 (4-(2-((7- amino-2-(furan-2-yl)-[1,2,4]triazolo[1,5-a][1,3,5]triazin-5-yl)amino)ethyl)phenol), displayed only minor differences in affinity, although they varied substantially in their dissociation rates from the receptor. We believe that such a combination of SKR and SAR analyses, as we have done with the $A_{2 A} R$, will have general importance for the superfamily of $G$ protein-coupled receptors, as it can serve as a new strategy to tailor the interaction between ligand and receptor.

\section{Introduction}

G protein-coupled receptors (GPCRs) are among the largest and most heavily investigated drug targets in the drug research community. Traditional early phase drug design and discovery campaigns of GPCRs largely depend on equilibrium affinity- or potency-based structure-activity relationships (SAR). This approach of lead optimization allows a quick synthesisevaluation feedback loop to pool abundant candidate compound assemblies for further drug evaluation. Nevertheless, this classical SAR approach does not seem to predict clinical efficacy very well, which is evidenced by the high levels of attrition during the translation of lead compound in vitro activity into in vivo and clinical evaluation. To address this issue, several recent reviews have emphasized the importance of binding kinetics, and in particular, the lifetime of a drug-target binary complex (i.e., drug-target residence time (RT)), as a critical differentiator and predictor for drug efficacy and safety. ${ }^{[1]}$ In addition to the RT, the association rate of a ligand-receptor interaction, which reflects the "target engagement time" (ET), should also be taken into consideration in the early phases of drug research. This is especially important for designing drugs that require a fast onset of action and potentially for drugs that act on temporarily existing targets, such as protein-protein interactions. ${ }^{[2]}$ Therefore, an extensive structure-kinetics relationship (SKR) investigation, in addition to the traditional SAR anal-

[a] D. Guo, L. Xia, J. P. D. van Veldhoven, M. Hazeu, T. Mocking, Dr. J. Brussee, Prof. A. P. IJzerman, Dr. L. H. Heitman

Division of Medicinal Chemistry

Leiden Academic Centre for Drug Research (LACDR)

P.O. Box 9502, 2300 RA Leiden (The Netherlands)

E-mail:I.h.heitman@lacdr.leidenuniv.nl

Supporting information for this article is available on the WWW under http://dx.doi.org/10.1002/cmdc.201300474. ysis, can be of great use in the early phases of candidate drug optimization.

The human adenosine $A_{2 A}$ receptor $\left(A_{2 A} R\right)$ is a subtype of adenosine receptors (other subtypes are $A_{1}, A_{2 B}$, and $A_{3}$ ) belonging to the superfamily of GPCRs. ${ }^{[3]}$ Antagonists for this receptor have been reported as potential treatment for Parkinson's disease. ${ }^{[4]}$ As such, many compounds with high $A_{2 A} R$ affinities have been developed ${ }^{[5]}$ including the reference antagonist ZM241385 (4-(2-((7-amino-2-(furan-2-yl)-[1,2,4]triazolo[1,5-a]$[1,3,5]$ triazin-5-yl)amino)ethyl)phenol), a triazolotriazine deriva-<smiles>CC(C)(C)NCc1nc(N)n2nc(-c3ccco3)nc2n1</smiles>

tive. ${ }^{[6]}$ These compounds were well characterized and optimized in terms of their binding affinity and thus benchmarked for later medicinal chemistry attempts targeting the $A_{2 A} R$. For example, $\mathrm{Vu}$ and colleagues synthesized ZM241385 derivatives with increased bioavailability. ${ }^{[7]}$ However, the success rate of the developed $A_{2 A} R$ antagonists in clinical trials is disappointingly low. On one hand, this indicates that the results of currently used preclinical animal models do not translate well into clinical studies. On the other hand, traditional, affinity-directed SAR alone may not be sufficient enough to select candidates for preclinical tests, especially when comparing compounds that are otherwise biologically or chemically similar. Although $A_{2 A} R$ antagonists have been previously investigated extensively in terms of their affinity or potency, little is known about their binding kinetics thus far. It is of great importance to be able to optimize the kinetic profiles of such compounds, in addition to 
their affinity, by medicinal chemistry efforts. Thus, we decided to further extend the series of ZM241385 derivatives by progressively modifying the $\mathrm{C}_{2}$ position to generate an insight into both SKR and SAR. We believe that the present study adds knowledge to our current understanding of drug design and development for $A_{2 A} R$ antagonists. Hopefully, this methodology of combining both SKR and SAR can be generally applied to other drug targets as well in the future.

\section{Results and Discussion}

\section{Chemical synthesis}

Synthesis routes are depicted in Schemes 1 and 2. In total, an ensemble of 24 triazolotriazine derivatives $(\mathbf{1 2} \mathbf{a}-\mathbf{x})$ was obtained. Notably, compounds $12 \mathrm{a}, 12 \mathrm{~b}$, and $12 \mathrm{x}$ were previously reported by $\mathrm{Vu}$ et al. ${ }^{[7 \mathrm{cc}}$ and were resynthesized in the present study, although using a different synthetic approach. All compounds (12a-x) were synthesized beginning from furan-2-carbohydrazide (1) to generate 7-amino2-(furyl)-5-methylthio[1,2,4]triazolo[1,5-a][1,3,5]triazine (4), following the synthetic approach reported by Dolzhenko et al. and Jörg et al. ${ }^{[8]}$ Subsequently, 4 was oxidized with 3-chloroperbenzoic acid ( $m C P B A$ ) to afford the corresponding sulfoxide/sulfone mixture $5^{[9]}$ which was substituted with a variety of commercially available amines $(\mathbf{1 1} \mathbf{f}-\mathbf{h})$ to generate $\mathbf{1 2} \mathbf{f}-\mathbf{h}$, or with in-house prepared amines (11 a-d and $\mathbf{1 1} \mathbf{i}-\mathbf{x})$ to generate $12 \mathrm{a}-\mathrm{d}$ and $12 \mathrm{i}-\mathbf{x}$. Compound $12 \mathrm{e}$ was obtained by the $\mathrm{N}$ Boc deprotection of $\mathbf{1 2} \mathbf{d}$.

For the preparation of intermediate amines $11 \mathbf{a}-\mathbf{d}$ and $\mathbf{1 1} \mathbf{i}-$ $\mathbf{x}$, synthetic routes are depicted in Scheme 2 . In brief, reactions<smiles>Cc1ccc(C(=O)NN=C(N)N)o1</smiles><smiles></smiles>

Scheme 1. General synthesis route to 24 triazolotriazine derivatives. Reagents and conditions: a) S-methylisothiourea sulfate $(2: 1), 4 \% \mathrm{NaOH}_{\text {(aq) }}$ room temp.; b) $\mathrm{H}_{2} \mathrm{O}$, room temp.; c) 1. $(\mathrm{MeS})_{2} \mathrm{C}=\mathrm{NCN}$, heat, $180^{\circ} \mathrm{C}, 2 . \mathrm{CH}_{2} \mathrm{Cl}_{2} / \mathrm{CH}_{3} \mathrm{OH}$ (2:1), reflux; d) $m C P B A$ (70\% strength), $\mathrm{CH}_{2} \mathrm{Cl}_{2}, 0^{\circ} \mathrm{C} \rightarrow$ room temp.; e) $\mathrm{Et}_{3} \mathrm{~N}, \mathrm{CH}_{3} \mathrm{CN}$. were carried out via $\mathrm{N}$-alkylation of the commercially available piperazine derivatives $(\mathbf{9} \mathbf{a}-\mathbf{d}$ and $\mathbf{9} \mathbf{i}-\mathbf{u})$ or the in-house synthesized phenylpiperazines $(\mathbf{9} \mathbf{v}-\mathbf{x})$, which were derived from 6$\mathbf{8}^{[10]}$ to obtain the appropriate $\mathrm{N}$-phthalimide-protected alkyl piperazines (10 a-d and $10 \mathbf{i}-\mathbf{x})$. This was followed by deprotection of the phthalimide to afford the free amines ( $11 \mathbf{a}-\mathbf{d}$ and $11 \mathrm{i}-\mathbf{x})$

\section{SAR and SKR of triazolotriazine derivatives}

The SAR and SKR analyses were initiated by testing two compounds, $12 \mathrm{a}$ and $\mathbf{1 2} \mathrm{b}$, then chemical modifications were gradually introduced to these two compounds (Table 1). Several observations were made: 1 ) the molecule with a twocarbon spacer was superior to the compound with a three-carbon spacer. The former $\left(12 \mathrm{a}, K_{\mathrm{i}}=0.30 \pm\right.$ $0.08 \mathrm{~nm} ; \mathrm{RT}=164 \pm 32 \mathrm{~min}$ ) displayed a fourfold higher affinity and 41-fold longer RT than the latter (12 b, $K_{\mathrm{i}}=1.3 \pm 0.1 \mathrm{~nm} ; \mathrm{RT}=4 \pm 1 \mathrm{~min}$ ). Such variation in linker length also resulted in different association rates $\left(12 \mathrm{a}, k_{\text {on }}=0.051 \pm 0.005 \mathrm{~nm}^{-1} \cdot \mathrm{min}^{-1} ; 12 \mathrm{~b}, k_{\text {on }}=\right.$ $\left.0.16 \pm 0.06 \mathrm{~nm}^{-1} \cdot \mathrm{min}^{-1}\right)$. 2) Upon different degrees of $\mathrm{C}_{2}$-phenylpiperazine modification, the ligand affinities were moderately to largely affected, while their receptor RT values were drastically shortened $(\mathbf{1 2} \mathbf{d}-\mathbf{h})$, except for the Boc-protected intermediate $\mathbf{1 2} \mathbf{d}$. This compound, in fact, had a 30- and 20-fold improved 
Table 1. Binding affinities and kinetics of ZM241385 and $\mathbf{1 2} \mathbf{a}-\mathbf{h}$.

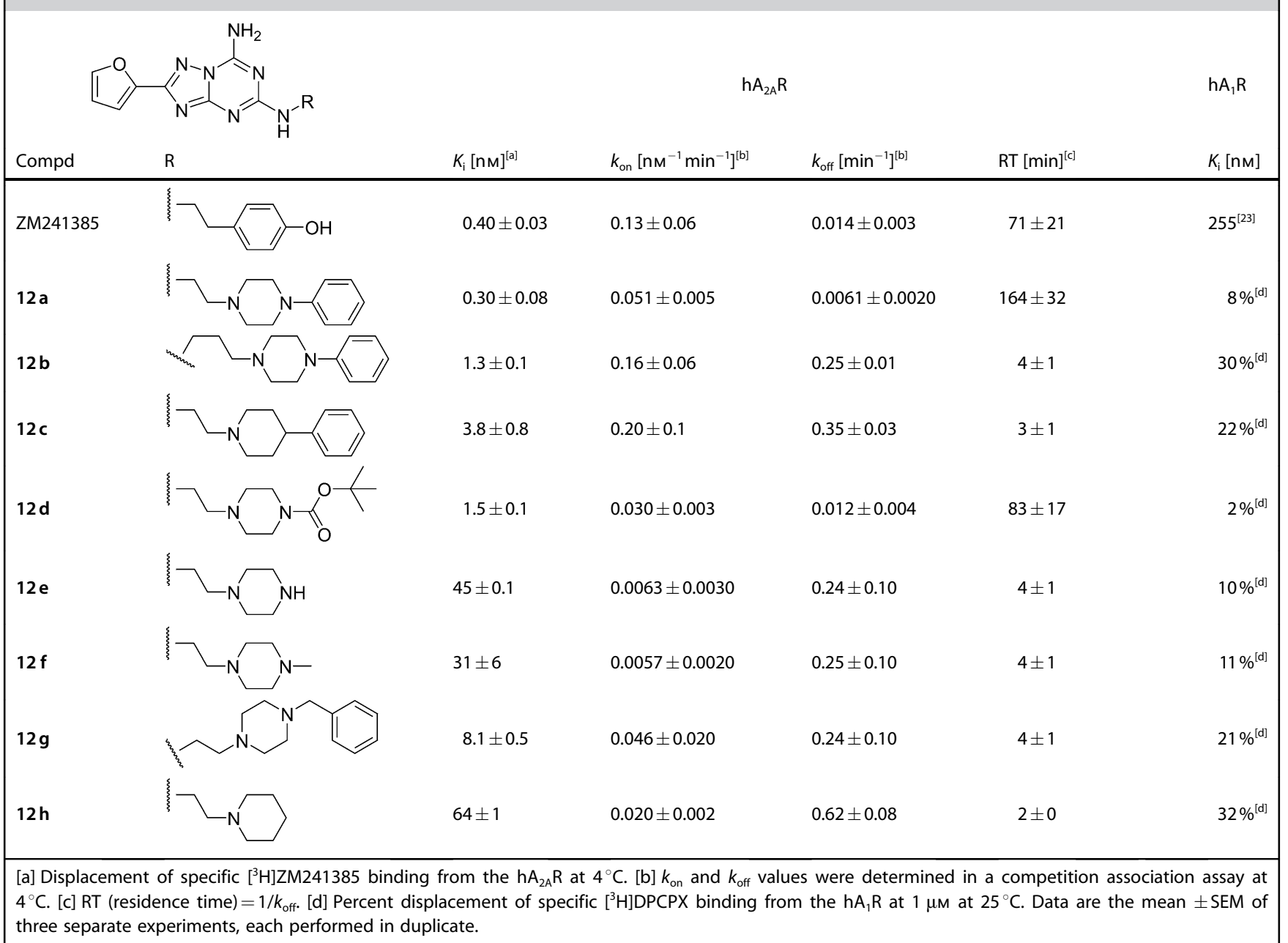

affinity and RT, respectively, relative to its truncated analogue (12e). Moreover, ET values were also significantly influenced by chemical modifications on the phenylpiperazine moiety. Specifically, $\mathbf{1 2} \mathbf{g}$ displayed the fastest association rate $(0.046 \pm$ $0.020 \mathrm{~nm}^{-1} \cdot \mathrm{min}^{-1}$ ). (3) Receptor RT values of $12 \mathrm{a}$ or $12 \mathrm{~d}$ highlight the preference for an electron-withdrawing effect at the piperazine amine moiety. The insertion of an additional carbon into $12 \mathrm{a}$ (between the piperazine and the phenyl group; $12 \mathrm{~g}$ ) reversed the electron-withdrawing effect to a donating effect, which resulted in decreased $A_{2 A} R$ affinity $(8.1 \pm 0.5 \mathrm{nM})$ and RT ( $4 \pm 1 \mathrm{~min}$ ). Replacement of the nitrogen by a carbon atom on the "right side" of the piperazine (compare 12a and 12c) resulted in strongly decreased RT values that further confirmed the importance of the nitrogen in maintaining $A_{2 A} R$ affinity and RT (Table 1, Figure 1 for $12 \mathrm{c}$ ). Notably, the ET and RT of $12 \mathrm{c}$ were the shortest for this series of compounds (except for the nearly 20-fold lower-affinity compound $12 \mathrm{~h}$ ) without a large compromise on affinity. Taken together, these results highlight the importance of the $C_{2}$-phenylpiperazine-ethyl group, and more specifically show that the electron-deficient nitrogen (on the right side of the piperazine) has a role in preserving a tight ligand-receptor interaction.
The SAR and SKR were further analyzed with 16 phenyl-substituted $12 \mathrm{a}$ analogues (Table 2, 12 $\mathbf{i}-\mathbf{x}$ ). Upon para substitution at the phenyl ring $(\mathbf{1 2} \mathbf{i}-\mathbf{n})$, no significant change in ligand affinity ( $K_{\mathrm{i}}$ values $<1 \mathrm{~nm}$ ) was observed, except for $12 \mathrm{n}$, which had a 4.7-fold decrease in affinity $(1.4 \pm 0.2 \mathrm{~nm})$. This decrease was probably caused by steric hindrance induced by the bulky phenyl substituent, which presumably also limited its RT to $29 \pm 2 \mathrm{~min}$ and decreased the association rate to $0.018 \pm$ $0.002 \mathrm{nM}^{-1} \cdot \mathrm{min}^{-1}$. In contrast, the other para-substituted compounds $(\mathbf{1 2} \mathbf{i}-\mathbf{m})$ displayed a similar duration of in vitro receptor occupancy as ZM241385 (RT=71 $\pm 21 \mathrm{~min}$ ). In comparison with the convergent results upon para-position modifications, ortho-substituted analogues (120-r) displayed divergent affinities and binding kinetics. Specifically, an ortho-methoxy substituent (12p) displayed decreased $A_{2 A} R$ affinity and RT relative to its para-substituted analogue (12 $\mathrm{m}$ ), while methyl- (12o) or halogen-substituted (12q, 12r) analogues displayed increased $A_{2 A} R$ affinities and RT values. For most compounds, disubstitution of the phenylpiperazine did not dramatically change their affinities or binding kinetics (12t-w). Interestingly for $\mathbf{1 2 x}$, which has ortho- and para-fluoro substituents, an exceptionally long receptor RT of $323 \pm 25$ min was found (Table 2) that was 
Table 2. Binding affinities and kinetics of compounds $12 \mathrm{i}-12 \mathrm{x}$.

\begin{tabular}{|c|c|c|c|c|c|c|}
\hline & & \multicolumn{4}{|c|}{$\mathrm{hA}_{2 \mathrm{~A}} \mathrm{R}$} & $h A_{1} R$ \\
\hline Compd & $\mathrm{R}$ & $K_{\mathrm{i}}[\mathrm{nm}]^{[\mathrm{a}]}$ & $k_{\mathrm{on}}\left[\mathrm{nM}^{-1} \cdot \mathrm{min}^{-1}\right]^{[\mathrm{b}]}$ & $k_{\text {off }}\left[\mathrm{min}^{-1}\right]^{[b]}$ & $\mathrm{RT}[\mathrm{min}]^{[\mathrm{c}]}$ & $K_{\mathrm{i}}[\mathrm{nm}]$ \\
\hline ZM241385 & Table 1 & $0.40 \pm 0.03$ & $0.13 \pm 0.06$ & $0.014 \pm 0.003$ & $71 \pm 21$ & $255^{[23]}$ \\
\hline $12 \mathrm{a}$ & $4-\mathrm{H}$ & $0.30 \pm 0.08$ & $0.051 \pm 0.005$ & $0.0061 \pm 0.0020$ & $164 \pm 32$ & $8 \%^{[\mathrm{d}]}$ \\
\hline $12 i$ & $4-\mathrm{CH}_{3}$ & $0.79 \pm 0.06$ & $0.062 \pm 0.020$ & $0.016 \pm 0.006$ & $63 \pm 18$ & $14 \%^{[\mathrm{d}]}$ \\
\hline $12 j$ & $4-\mathrm{Cl}$ & $0.29 \pm 0.10$ & $0.090 \pm 0.010$ & $0.018 \pm 0.006$ & $56 \pm 11$ & $35 \pm 13$ \\
\hline $12 \mathrm{k}$ & $4-\mathrm{CF}_{3}$ & $0.38 \pm 0.10$ & $0.072 \pm 0.009$ & $0.020 \pm 0.005$ & $50 \pm 37$ & $64 \%{ }^{[d]}$ \\
\hline 121 & $4-\mathrm{F}$ & $0.54 \pm 0.05$ & $0.10 \pm 0.02$ & $0.020 \pm 0.005$ & $50 \pm 8$ & $57 \%{ }^{[\mathrm{d}]}$ \\
\hline $12 \mathrm{~m}$ & $4-\mathrm{OCH}_{3}$ & $0.51 \pm 0.10$ & $0.064 \pm 0.005$ & $0.0079 \pm 0.0020$ & $127 \pm 19$ & $11 \%^{[\mathrm{d}]}$ \\
\hline $12 n$ & 4-Ph & $1.4 \pm 0.2$ & $0.018 \pm 0.002$ & $0.034 \pm 0.010$ & $29 \pm 2$ & $32 \%{ }^{[d]}$ \\
\hline 120 & $2-\mathrm{CH}_{3}$ & $0.13 \pm 0.04$ & $0.062 \pm 0.002$ & $0.0075 \pm 0.0020$ & $133 \pm 21$ & $29 \%{ }^{[\mathrm{d}]}$ \\
\hline $12 p$ & $2-\mathrm{OCH}_{3}$ & $3.5 \pm 0.7$ & $0.032 \pm 0.003$ & $0.070 \pm 0.070$ & $14 \pm 11$ & $19 \%^{[\mathrm{d}]}$ \\
\hline $12 q$ & $2-\mathrm{Cl}$ & $0.13 \pm 0.03$ & $0.068 \pm 0.016$ & $0.0065 \pm 0.0010$ & $154 \pm 25$ & $30 \%$ [d] \\
\hline $12 r$ & $2-F$ & $0.12 \pm 0.05$ & $0.052 \pm 0.012$ & $0.011 \pm 0.002$ & $91 \pm 15$ & $28 \%^{[d]}$ \\
\hline $12 \mathrm{~s}$ & $3-\mathrm{F}$ & $0.29 \pm 0.03$ & $0.055 \pm 0.009$ & $0.012 \pm 0.003$ & $83 \pm 14$ & $62 \%{ }^{[d]}$ \\
\hline $12 t$ & 2,4-diCH ${ }_{3}$ & $0.16 \pm 0.01$ & $0.11 \pm 0.02$ & $0.012 \pm 0.001$ & $78 \pm 9$ & $29 \% \%^{[d]}$ \\
\hline $12 u$ & 3,4-diCl & $0.31 \pm 0.10$ & $0.10 \pm 0.01$ & $0.015 \pm 0.004$ & $67 \pm 11$ & $21 \pm 4$ \\
\hline $12 \mathrm{v}$ & 2,4-diCl & $0.15 \pm 0.02$ & $0.11 \pm 0.01$ & $0.014 \pm 0.001$ & $70 \pm 5$ & $80 \pm 24$ \\
\hline $12 w$ & $2-\mathrm{F}, 4-\mathrm{OCH}_{3}$ & $0.24 \pm 0.05$ & $0.054 \pm 0.005$ & $0.0083 \pm 0.0010$ & $120 \pm 65$ & $27 \%^{[\mathrm{d}]}$ \\
\hline $12 x$ & 2,4-diF & $0.33 \pm 0.04$ & $0.034 \pm 0.004$ & $0.0031 \pm 0.0002$ & $323 \pm 25$ & $22 \% \%^{[d]}$ \\
\hline
\end{tabular}

[a] Displacement of specific $\left[{ }^{3} \mathrm{H}\right] \mathrm{ZM} 241385$ binding from the $\mathrm{hA}_{2 \mathrm{~A}} \mathrm{R}$ at $4^{\circ} \mathrm{C}$. [b] $k_{\text {on }}$ and $k_{\text {off }}$ values were determined in a competition association assay at $4{ }^{\circ} \mathrm{C}$. [c] RT (residence time) $=1 / \mathrm{k}_{\text {off. }}$ [d] Percent displacement of specific $\left[{ }^{3} \mathrm{H}\right] \mathrm{DPCPX}$ binding from the $\mathrm{hA}, \mathrm{R}$ at $1 \mu \mathrm{M}$ at $25^{\circ} \mathrm{C}$. Data are the mean $\pm \mathrm{SEM}$ of three separate experiments, each performed in duplicate.

much longer than the simple sum of the RT values of the monofluorinated analogues (12 I, 12 r, and $12 \mathrm{~s}$ ) and almost fivefold longer than the RT of ZM241385. From Figure 1B, it also follows that $12 \mathrm{x}$ had a much longer RT than ZM241385 (the radioligand), as a typical "overshoot" in specific radioligand binding was observed. ${ }^{[11]}$ By contrast, if a competitor dissociates faster from its target than the radioligand, the specific binding of the radioligand will slowly and monotonically approach equilibrium over time, as observed for 12c (Figure $1 \mathrm{~B}) .^{[11]}$

Almost all prepared phenylpiperazine triazolotriazine derivatives displayed high selectivity over the human adenosine $A_{1}$ receptor $\left(A_{1} R\right)$, i.e., $<50 \%$ of $\left[{ }^{3} H\right] D P C P X$ displacement on $A_{1} R$ at $1 \mu \mathrm{M}$ (Tables 1 and 2). Notably, the compound with the longest RT toward $A_{2 A} R, 12 x$, had very good $A_{2 A} R$ selectivity over the $A_{1} R$ (Table 2). In contrast, $12 \mathbf{j}, \mathbf{1 2} \mathbf{u}$, and $12 \mathrm{v}$, with monoor dichloro substitution, lost some selectivity over the $A_{1} R\left(K_{i}\right.$ values at the $A_{1} R$ ranged from $20 \mathrm{~nm}$ to $80 \mathrm{~nm}$, Table 2). Interestingly, all of these compounds contain a chloro substituent in the para position, yet this substituent in other positions (e.g., 12 q, ortho substituent) did not exhibit lower selectivity for the $A_{2 A} R$ over the $A_{1} R$.

\section{Functional characterization of $12 x$ and $12 \mathrm{c}$ in a cAMP assay}

Subsequently, the compounds with the longest and shortest RT with high affinity (i.e., $12 x$ and $12 \mathrm{c}$ ) were functionally characterized in an $\mathrm{A}_{2 \mathrm{~A}} \mathrm{R}$ agonist-induced CAMP assay, which revealed their antagonistic behavior. Firstly, it follows from Figure $1 \mathrm{C}$ that both $12 \mathrm{x}$ and $12 \mathrm{c}$ induced a concentration-dependent decrease of intracellular CAMP levels with 16-fold difference in their $\mathrm{IC}_{50}$ values, which were $1.4 \pm 0.1 \mathrm{nM}$ and $21.8 \pm$ $0.5 \mathrm{~nm}$, respectively (Table 3 ). Secondly, pre-treatment of HEK293 hA ${ }_{2 A} R$ cells with different concentrations of $12 x$ before stimulation with an $A R$ agonist (i.e., $5^{\prime}-N$-ethylcarboxamidoadenosine, NECA) induced insurmountable antagonism (Table 3). In other words, the NECA concentration-effect curve was shifted to the right, with a concomitant decrease in the maximal

\begin{tabular}{|c|c|c|c|c|c|c|}
\hline \multirow[t]{2}{*}{ Compd } & \multirow{2}{*}{$\mathrm{IC}_{50}[\mathrm{~nm}]^{[\mathrm{a}]}$} & \multicolumn{2}{|c|}{ Pre-incubation ${ }^{[\mathrm{a}]}$} & \multicolumn{2}{|c|}{ Co-incubation $^{[\mathrm{a}]}$} & \multirow{2}{*}{ Mode of antagonism ${ }^{[b]}$} \\
\hline & & $\mathrm{pA}_{2}$ & Schild slope & $\mathrm{pA}_{2}$ & Schild slope & \\
\hline $12 \mathrm{c}$ & $1.4 \pm 0.1$ & $8.62 \pm 0.29$ & $0.93 \pm 0.11$ & $8.57 \pm 0.06$ & $0.93 \pm 0.02$ & Competitive surmountable \\
\hline $12 x$ & $21.8 \pm 0.5$ & NA & NA & $9.69 \pm 0.03$ & $1.13 \pm 0.01$ & Competitive insurmountable \\
\hline
\end{tabular}

[a] Antagonist potency values were determined from concentration-response curves for $12 \mathrm{x}$ and $12 \mathrm{c}$ in the presence of $100 \mathrm{nM}$ NECA with a 30 min co-incubation; antagonists were pre-incubated for $30 \mathrm{~min}$ or co-incubated with NECA at concentrations ranging from $100 \mu \mathrm{M}$ to $0.1 \mathrm{~nm}$. Data are the mean \pm SEM of three separate experiments, each performed in duplicate at $22-25^{\circ} \mathrm{C}$. NA: not available. [b] See text for further explanation. 
a)

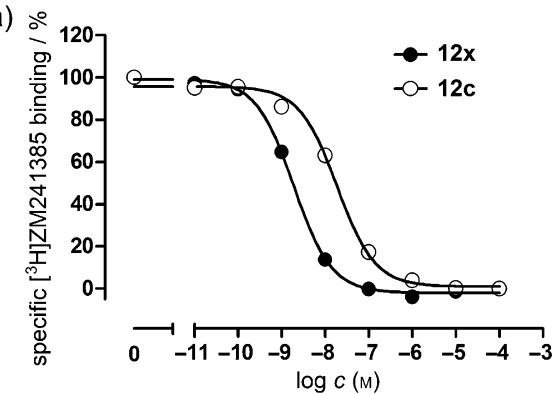

b)

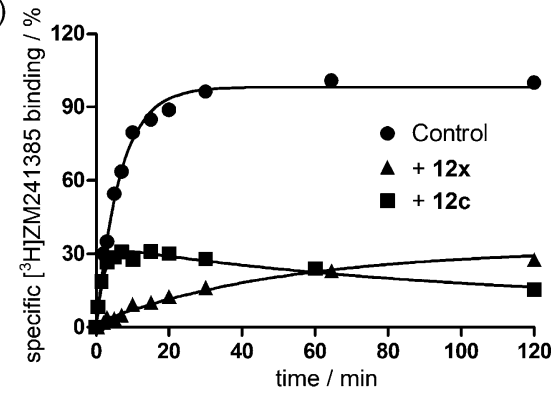

c)

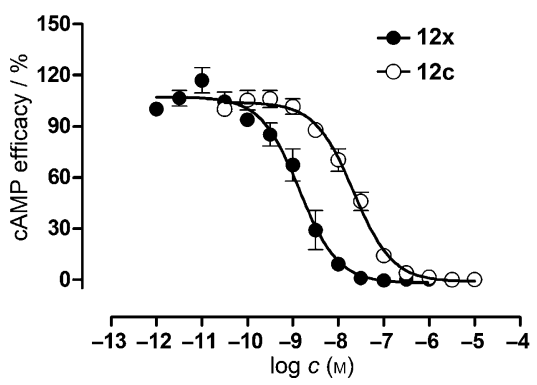

Figure 1. a) Displacement of specific $\left.{ }^{3} \mathrm{H}\right] \mathrm{ZM} 241385$ binding from the $h A_{2 A}$ receptor by two representative compounds, namely $12 \mathrm{x}$ and $12 \mathrm{c}$. b) $\left[{ }^{3} \mathrm{H}\right] Z \mathrm{ZM} 241385$ competition association binding in the absence of ligand (control) and in the presence of $10 \times K_{\mathrm{i}}$ of unlabeled $12 \mathrm{x}$ or $12 \mathrm{c}$. Data were fitted to the equation described in the Experimental section to calculate the $k_{\text {on }}$ and $k_{\text {off }}$ values for unlabeled ligands. Representative graphs are from one experiment performed in duplicate (see Tables 1 and 2 for affinity and kinetic values); c) Concentration-effect curves for $12 \mathrm{x}$ and $\mathbf{1 2} \mathrm{c}$ in a CAMP assay (percentage relative to $100 \mu \mathrm{M}$ NECA). Data were obtained by adding HEK293 $\mathrm{hA}_{2 \mathrm{~A}} \mathrm{R}$ cells to the mixture of the antagonist $(12 \mathrm{x}$ or $12 \mathrm{c})$ and $100 \mathrm{nM}$ NECA for a 30 min incubation. Data are expressed as mean \pm SEM from at least three independent experiments (see Table 3 for potency values).

response (Figure $2 \mathrm{~A}$ ). Conversely, $12 \mathrm{c}$ displayed surmountable $A_{2 A} R$ antagonism (Table 3), shifting the NECA curve to the right without affecting its maximal response (Figure $2 \mathrm{~B}$ ). In addition, the $\mathrm{pA}_{2}$ value for $12 \mathrm{c}$ generated from a Schild plot was $8.62 \pm$ 0.29 , which was similar to its $\mathrm{p} K_{\mathrm{i}}$ value $(8.40 \pm 0.10)$, and the Schild slope was close to unity $(0.93 \pm 0.11)$, suggesting that $12 \mathrm{c}$ competed with NECA for the same receptor binding site. To further examine whether $12 \mathrm{x}$ and $12 \mathrm{c}$ both bound to the same site as the agonist, we also performed a co-incubation experiment with $12 \mathrm{x}$ or $12 \mathrm{c}$ in the presence of NECA. It follows from Figure $2 \mathrm{C}, \mathrm{D}$ that in this experimental setup, both compounds produced a shift to the right in the NECA dose-response curve without suppression of the maximal response, indicative of a competitive interaction. Hence, these findings oppose that insurmountable antagonism resulted from an allo- steric mode of inhibition, which would be proven by suppression of the maximal response in the co-incubation experiment. ${ }^{[12]}$ Notably, the generated $\mathrm{pA}_{2}$ values of $12 \mathrm{x}$ and $12 \mathrm{c}$ in this experimental setup were similar to their $\mathrm{p} K_{\mathrm{i}}$ values, and the derived Schild slopes were close to unity (Table 3 ). Together, this confirmed that $12 \mathrm{x}$ or $12 \mathrm{c}$ bound fully competitively with NECA, and the insurmountable $A_{2 A} R$ antagonism of $12 x$ was a result caused by so-called hemi-equilibrium during the functional assay, due to its long $A_{2 A} R$ RT profile. ${ }^{[12 b]}$

It needs to be pointed out that functional characterization and determination of antagonist binding kinetics were performed at $4{ }^{\circ} \mathrm{C}$ and thus do not reflect in vivo RT values, that is, at body temperature. However, it is reasonable to expect that the ranking of the compound RT values at $4{ }^{\circ} \mathrm{C}$ will agree with those at higher, more physiological, temperatures. One example at the $A_{2 A} R$ is the agonist UK432097, which has previously been shown to have a fivefold longer RT than agonist CGS21680. ${ }^{[15 b]}$ This difference at $4{ }^{\circ} \mathrm{C}$ apparently translates into a distinct duration of action in vivo reported by Mantell et al., that is, $8 \mathrm{~h}$ for UK432097 and less than $1 \mathrm{~h}$ for CGS21680. ${ }^{[14]}$

\section{Generation of a kinetics map and physicochemical correlation plots}

Next, we plotted an on-/off-rate graph, or "kinetics map", including the data for all $A_{2 A} R$ ligands obtained in this study (Figure 3). ${ }^{[13]}$ This kinetics map depicted the ligand-receptor binding affinity ( $K_{\mathrm{D}}$, represented by parallel diagonal lines) as detailed kinetic rates that reflect the process of target ET ( $k_{\text {on }}$ $y$ axis) and the target RT ( $k_{\text {off }} x$ axis), respectively. We observed that the compounds can be divided into three groups: firstly, both the $k_{\text {on }}$ and $k_{\text {off }}$ values could vary by one order of magnitude (Figure 3, Group A), while the $K_{\mathrm{D}}$ remained within a narrow range $(0.1-0.3 \mathrm{~nm})$, as mentioned above. This indicated that compounds with the same affinity may have many different combinations of on- and off-rates, even within the same scaffold and target system. Such information, often ignored or unavailable in traditional SAR studies, can in fact be highly decisive in translating the in vitro profile in of a lead to in vivo pharmacokinetics (PK) and/or pharmacodynamics (PD) behavior. ${ }^{[14]}$ Secondly, compounds sharing the same off-rate may bear divergent $K_{\mathrm{D}}$ values, due to different on-rates (Group B). It has been shown in several cases that a slow compound dissociation rate is pivotal for high in vivo efficacy. ${ }^{[15]}$ Thus, in retrospect, one could imagine that many compounds with promising $k_{\text {off }}$ values were overlooked simply due to their low scores in classical affinity- or potency-dominated evaluations. Thirdly, the same holds for a compound's on-rate (Group C), i.e., merely focusing on the $K_{\mathrm{D}}$ value of a ligand can result in compounds without the desired on-rate, as exemplified by candidate drugs aimed at acute diseases where a rapid onset of action is desired (e.g., acute respiratory distress syndrome). ${ }^{[2, f]}$ Taken together, the kinetics map provides a detailed interpretation of a ligand-receptor binding process with a full inventory of $k_{\text {on }}, k_{\text {off }}$ and $K_{\mathrm{D}}$ values of a series of compounds.

Molecular and physicochemical properties of the synthesized phenylpiperazine analogues (12i-x and $12 a$ ) and their puta- 
a)
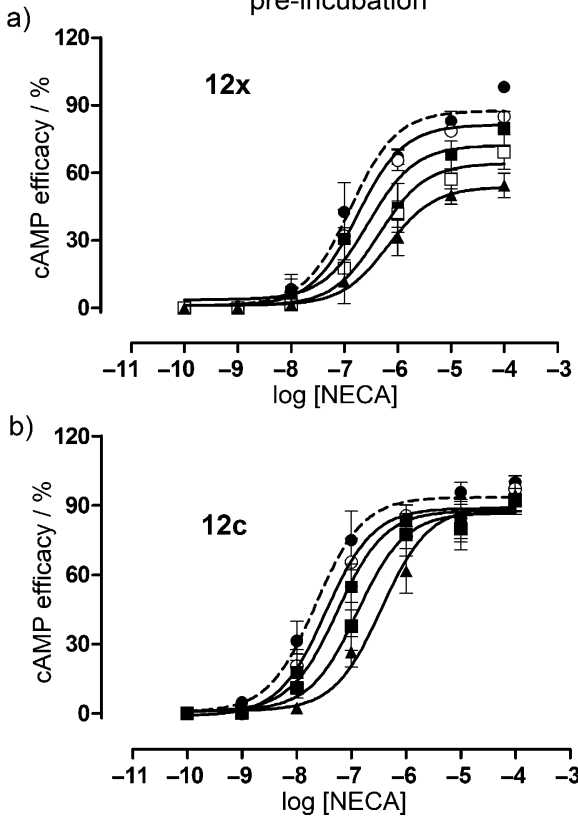

c)

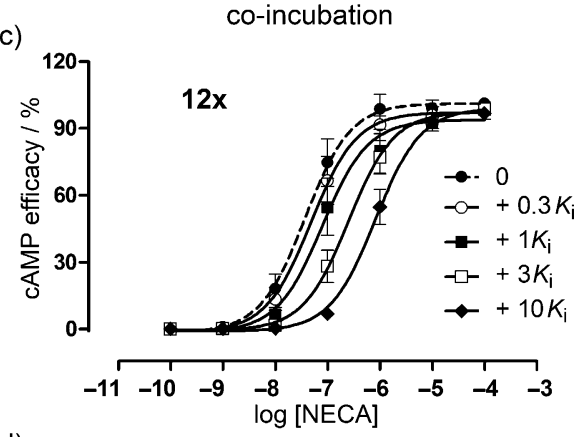

d)

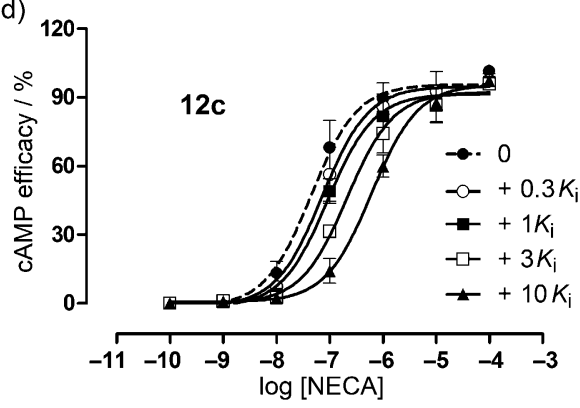

Figure 2. CAMP experiments were performed on HEK293 human embryonic kidney cells stably expressing the $h A_{2 A} R$ at room temperature $\left(22-25^{\circ} \mathrm{C}\right)$. a) $12 x$ or b) $12 \mathrm{c}$ were incubated for 30 min prior to challenge of the adenosine receptor agonist NECA at concentrations ranging from $100 \mu \mathrm{M}$ to $0.1 \mathrm{~nm}$ for another $30 \mathrm{~min}$. c) $12 \mathrm{x}$ or d) $12 \mathrm{c}$ were co-incubated with NECA at concentrations ranging from $100 \mu \mathrm{M}$ to $0.1 \mathrm{~nm}$ for $30 \mathrm{~min}$. The agonist curves were generated in the presence of increasing concentrations of antagonist, namely 0.3-, 1-, 3- and 10-fold their respective $K_{\mathrm{i}}$ values. Data were normalized according to the maximal response produced by $100 \mu \mathrm{M}$ NECA. The shift in agonist $\mathrm{EC}_{50}$ was determined to perform Schild analyses. Data are expressed as mean $\pm \mathrm{SEM}$ from at least three independent experiments performed in duplicate.

is the same, we specifically focused on the properties of $\mathrm{C}_{2}$ phenylpiperazine fragments. Several descriptors were selected to be further examined in correlation plots. These included the size (molecular weight, $M_{r}[D a]$ ), surface (molecular surface area, MSA), lipophilicity $(\log P)$, and charge (ionization constant, $\mathrm{p} K_{\mathrm{a}}$ ) of the fragment. There was no obvious linear correlation between the association/dissociation rates and $M_{r}, \log P, M S A$, or $\mathrm{p} K_{\mathrm{a}}$ values. We also performed a multiple linear regression analysis to check whether compound binding kinetics were directed by a combination of two or more of the physicochemical descriptors. However, no significant correlation was found (significance $F>0.05$ in all cases). Altogether, this indicated that the binding kinetics were compound-specific and that there is no general trend in the correlation of their molecular and physicochemical properties.

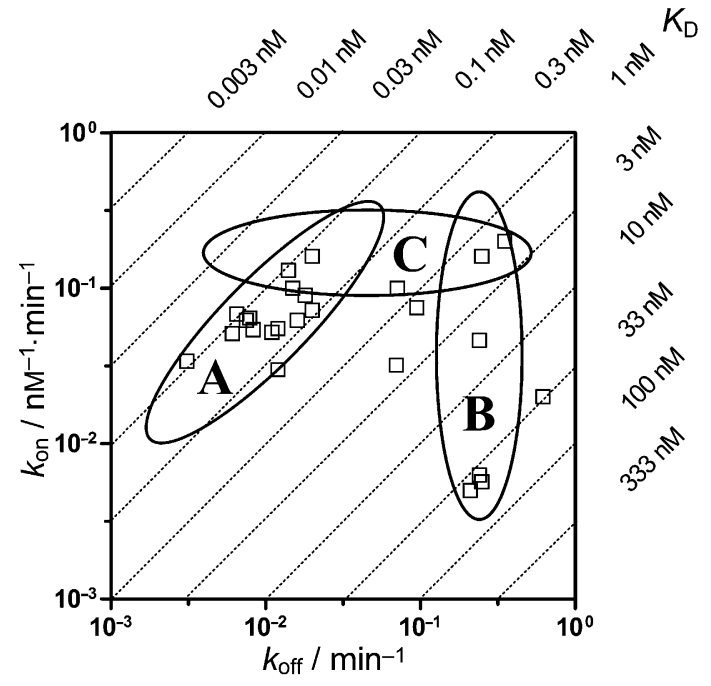

Figure 3. Kinetics map ( $y$ axis: $k_{\mathrm{on}}, \mathrm{nM}^{-1} \cdot \min ^{-1} ; x$ axis: $k_{\text {off }}, \min ^{-1}$ ) of all $\mathrm{A}_{2 \mathrm{~A}} \mathrm{R}$ ligands tested in this study. The kinetically derived affinity $\left(K_{D}=k_{\text {off }} / k_{\text {on }}\right)$ is represented by parallel diagonal lines. Group A: compounds that had varied $k_{\text {on }}$ and $k_{\text {off }}$ values across several orders of magnitude, while the $K_{\mathrm{D}}$ remained within a similar range (0.1-0.3 nM). Group B: compounds that had the same $k_{\text {off }}$ values, but divergent $K_{\mathrm{D}}$ values. Group C: compounds that had the same $k_{\text {on }}$ values, but divergent $K_{\mathrm{D}}$ values.

tive relationship with the on- and off-rates were examined in efforts to identify key factor(s) affecting their binding kinetics (Figure 4). As the main scaffold of these series of compounds

\section{Importance of the $\mathrm{C}_{2}$-phenylpiperazine fragment and its location}

In this study, we observed that, upon minor chemical modifications of the phenylpiperazine side chain on the triazolotriazine scaffold (Tables 1 and 2), binding affinity of the derivatives underwent only subtle changes, while their binding kinetics were very sensitive to such structural variations. For instance, upon substitution of $12 \mathrm{a}, \mathbf{1 2} \mathbf{k}$ (para-trifluoromethyl substituted) displayed a similar $K_{\mathrm{i}}$ value as $12 \mathrm{a}$, while its off-rate was increased 3.4-fold. In another case, the on- and off-rates of $12 \mathrm{u}$ (meta-, para-chloro disubstituted) were increased and decreased, respectively, by a similar magnitude (approximately twofold), leading to an unchanged affinity value relative to $12 \mathrm{a}$. Table 2 as a whole exemplifies the difficulty of selecting a next-stage candidate based on SAR alone. Most compounds have subnanomolar affinity, and compound $12 \mathrm{x}$ does not stand out in any particular way.

The lack of large changes in binding affinities might be expected, given the absence of direct interactions between the phenylhydroxy group and the receptor in a recently determined high-resolution crystal structure of ZM241385-bound $A_{2 A} R \cdot{ }^{[17]}$ In this structure, the phenylhydroxy group points away from the binding pocket toward the extracellular space. Likewise, in another crystal structure of UK432097-bound $A_{2 A} R$, the bulky tail of agonist UK432097 at the adenine $C_{2}$ position extends out of the ligand-binding cavity. ${ }^{[18]}$ Notably, it was re- 

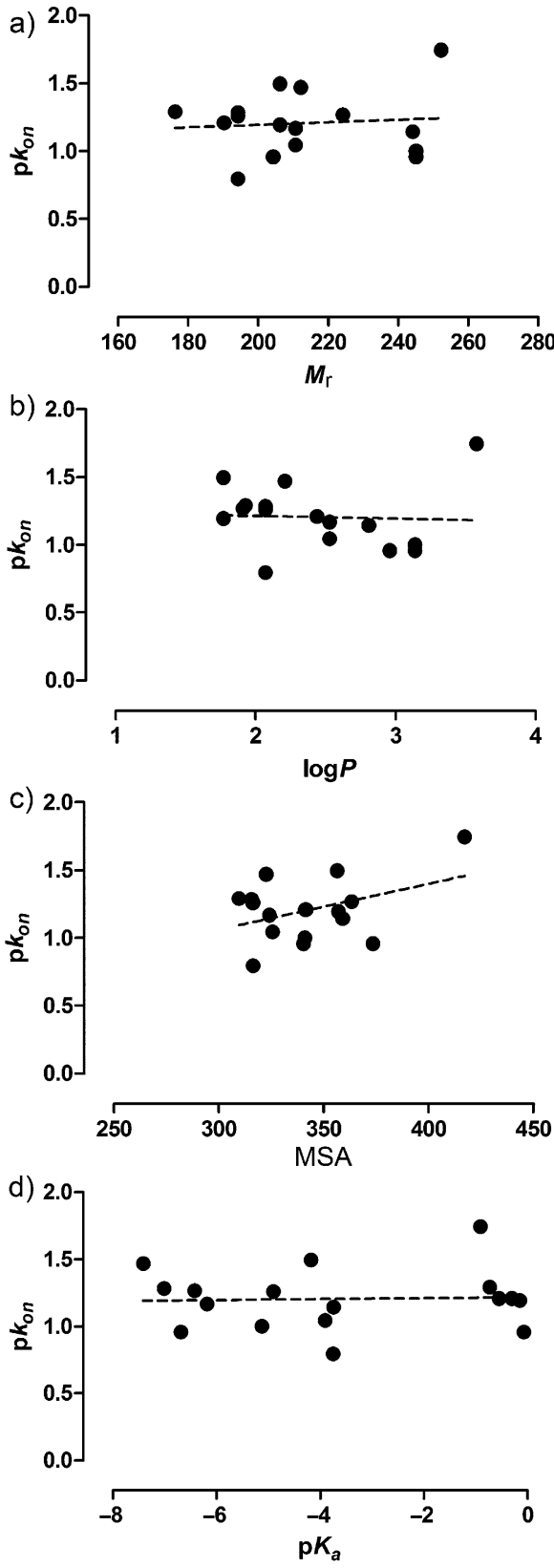
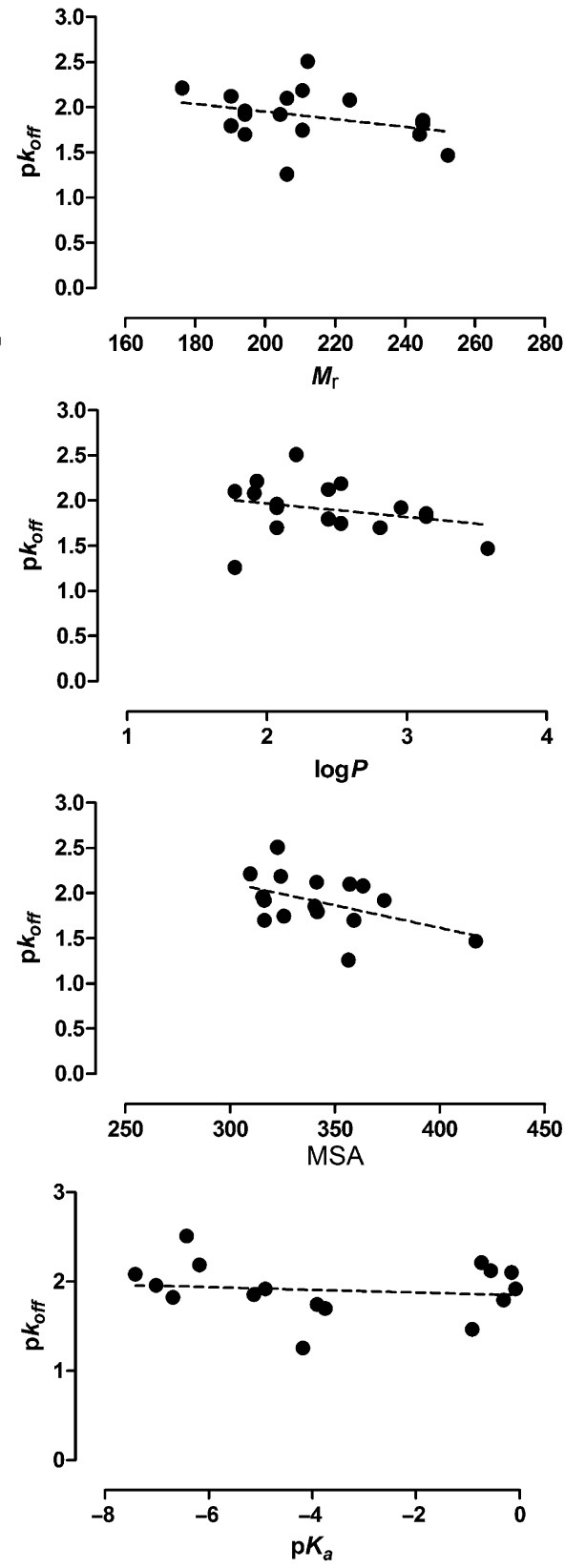

study of the $\beta_{1}$ - and $\beta_{2}$-adrenergic receptors by Dror et al. ${ }^{[19]}$ They found that several beta blockers and one beta agonist all traverse the same well-defined, dominant pathway as they bind to the $\beta_{1}$ - and $\beta_{2}$-adrenergic receptors, initially making contact with a so-called "vestibule" on the receptor's extracellular surface. Interestingly, this holds true for the ligand binding dynamics of the $M_{3}$ muscarinic acetylcholine receptor too. Simulation results indicated that as tiotropium binds to or dissociates from the receptor, it pauses at an alternative binding site in the extracellular vestibule. ${ }^{[20]}$ Taken together, such an extracellular vestibule appears to play an important role in the on- or off-trajectory to and from the binding pocket of a GPCR. ${ }^{[19]}$ We therefore assume that the derivatives of ZM241385 also transiently interact with a similar extracellular region of the $A_{2 A} R$. This is in accordance with our observation that a change in the $C_{2}$-phenylpiperazine group significantly affected the ligand association and dissociation rates at the $\mathrm{A}_{2 \mathrm{~A}} \mathrm{R}$, while their $K_{\mathrm{i}}$ values were minimally changed.

\section{Conclusions}

We have exemplified an extensive SKR in addition to a traditional SAR analysis at the $A_{2 A} R$. Compound $\mathbf{1 2 x}$, the high-affinity $A_{2 A} R$ ligand previously reported by $\mathrm{Vu}$ et al., ${ }^{[7 \mathrm{c}]}$ was revealed to have an exceptionally long RT (323 min). Compared with traditional SAR analysis, such a kinetic insight provided a further ration-

Figure 4. Molecular descriptors of a) size $\left(M_{\mathrm{r}}\right)$, b) lipophilicity $\left.(\log P), \mathrm{c}\right)$ molecular surface area $(\mathrm{MSA}, 3 \mathrm{D})$, and d) charge $\left(\mathrm{p} K_{\mathrm{a}}\right)$ of the substituted $\mathrm{C}_{2}$-phenylpiperazine fragments and their correlation with the log values of on(left side) and off-rates (right side). No clear linear correlation was observed between the association/dissociation rates and $M_{\mathrm{r}}$ (for association: $R^{2}=0.0089, P=0.7180$; for dissociation: $R^{2}=0.1059, P=0.2024$ ), $\log P$ (for association $R^{2}=0.0023, P=0.8563$; for dissociation: $R^{2}=0.0731, P=0.2938$ ), MSA (for association: $R^{2}=0.1629, P=0.1082$; for dissociation: $R^{2}=0.2107, P=0.0638$ ), or $\mathrm{p} K_{\mathrm{a}}$ (for association: $R^{2}=0.0018, P=0.8727$; for dissociation: $R^{2}=0.0187$, $P=0.6010)$.

cently published that this agonist also has a slow association rate and a long $R T$ at the $A_{2 A} R \cdot{ }^{[15 b]}$ Based on these findings, we postulated that the $C_{2}$-phenylpiperazine group protrudes outward without forming direct interactions with residues in the binding pocket of the triazolotriazine core. Instead, it may interact with residues that are located in the extracellular loops or the adjacent regions of the binding cavity along its trajectory of associating to or dissociating from the receptor. Such reasoning is supported by a recent molecular dynamics simulation ale to support the selection of $\mathbf{1 2 x}$ from otherwise chemically and biologically similar compounds for further testing. Kinetics mapping of all tested $\mathrm{A}_{2 \mathrm{~A}} \mathrm{R}$ ligands also provided a detailed interpretation of the ligand-receptor binding process. Next, a functional comparison between $12 \mathrm{c}$ and $12 \mathrm{x}$ in different assay formats (co-application versus pre-incubation) further revealed competitive insurmountable antagonism of $12 x$ at the $\mathrm{hA}_{2 \mathrm{~A}} \mathrm{R}$ - $\mathrm{a}$ phenomenon distinct from that of $12 \mathrm{c}$. In addition, investigation of the molecular properties indicated that the 
ligand-receptor binding kinetics were most likely driven by specific interactions between the ligand and the receptor. As an extension of the current study, it would be of great interest to subject compounds having similar affinity yet different binding kinetics to (pre)clinical tests. This would show how relevant the variations in RT and on-/off-rates are in terms of in vivo efficacy and duration of action. We believe that SKR, in combination with traditional SAR, can serve as an important tool for more directed medicinal chemistry efforts in the future.

\section{Experimental Section}

\section{Chemical synthesis}

General: All solvents and reagents were purchased from commercial sources and were of analytical grade. Demineralized water is simply referred to as $\mathrm{H}_{2} \mathrm{O}$ and was used in all cases unless stated otherwise (i.e., brine). ${ }^{1} \mathrm{H}$ and ${ }^{13} \mathrm{C}$ NMR spectra were recorded on a Bruker AV 400 liquid spectrometer $\left({ }^{1} \mathrm{H} N M R, 400 \mathrm{MHz} ;{ }^{13} \mathrm{C} \mathrm{NMR}\right.$, $101 \mathrm{MHz}$ ) at room temperature. Chemical shifts are reported in parts per million (ppm), are designated by $\delta$, and are downfield of the internal standard tetramethylsilane (TMS). Coupling constants are reported in $\mathrm{Hz}$ and are designated as $\mathrm{J}$. High-resolution mass spectrometry was performed by the Leiden Institute of Chemistry and recorded by direct injection ( $2 \mu \mathrm{L}$ of a $2 \mu \mathrm{M}$ solution in $\mathrm{H}_{2} \mathrm{O}$ / $\mathrm{CH}_{3} \mathrm{CN} ; 50: 50 ; \mathrm{v} / \mathrm{v}$ and $0.1 \%$ formic acid) on a mass spectrometer (Thermo Finnigan LTQ Orbitrap) equipped with an electrospray ion source in positive mode (source voltage $3.5 \mathrm{kV}$, sheath gas flow 10 , capillary temperature $275^{\circ} \mathrm{C}$ ), with resolution $(R)=60000$ at $\mathrm{m} / \mathrm{z}$ 400 (mass range $m / z=150-2000$ ) and calibrated for dioctylphthalate $(m / z=391.28428)$. Analytical purity of the final compounds was determined by high performance liquid chromatography (HPLC) with a Phenominex Gemini 3u C18 110A column (50x $4.6 \mathrm{~mm}, 3 \mu \mathrm{m}$ ), measuring UV absorbance at $254 \mathrm{~nm}$. Sample preparation and HPLC method were as follows, unless stated otherwise: $0.3-0.8 \mathrm{mg}$ of compound was dissolved in $1 \mathrm{~mL}$ of a 1:1:1 mixture of $\mathrm{CH}_{3} \mathrm{CN} / \mathrm{H}_{2} \mathrm{O} / \mathrm{tBuOH}$ and eluted from the column within $15 \mathrm{~min}$, with a three-component system of $\mathrm{H}_{2} \mathrm{O} / \mathrm{CH}_{3} \mathrm{CN} / 1 \%$ TFA in $\mathrm{H}_{2} \mathrm{O}$, decreasing polarity of the solvent mixture over time from 80:10:10 to $90: 0: 10$. All compounds showed a single peak at the designated RT and are at least $95 \%$ pure. Thin-layer chromatography (TLC) was routinely consulted to monitor the progress of reactions, using aluminum-coated Merck silica gel $F_{254}$ plates. Purification by column chromatography was achieved by use of Grace Davison Davisil silica column material (LC60A, 30-200 $\mu \mathrm{m})$. Solutions were concentrated using a Heidolph Laborota W8 2000 evaporation apparatus and by high vacuum on a Binder APT line vacuum drying oven. The procedure for a series of similar compounds is given as a general procedure for all within that series, annotated by the numbers of the compounds.

2-(Furan-2-carboxamido) guanidine (2): A mixture of hydrazide $1(0.1 \mathrm{~mol}, 12.6 \mathrm{~g})$ and $\mathrm{S}$-methylisothiourea sulfate $(0.05 \mathrm{~mol}$, $13.9 \mathrm{~g})$ in an $1 \%$ aqueous $\mathrm{NaOH}$ solution $(400 \mathrm{~mL})$ was stirred at room temperature for $72 \mathrm{~h}$. The precipitated solid (2), was filtered, washed with ice water, and used in next step without further purification: ${ }^{1} \mathrm{H}$ NMR $\left(400 \mathrm{MHz},\left[\mathrm{D}_{6}\right] \mathrm{DMSO}\right): \delta=10.77$ (brs, $\left.1 \mathrm{H}, \mathrm{NH}\right)$, $7.56(\mathrm{~s}, 1 \mathrm{H}), 6.88$ and $6.76\left(2 \times \mathrm{s}\right.$ due to dimer formation, $\left.2 \mathrm{H}, \mathrm{NH}_{2}\right)$, $6.64(\mathrm{~d}, J=2.8 \mathrm{~Hz}, 1 \mathrm{H}), 6.45 \mathrm{ppm}(\mathrm{dd}, J=2.0,0.8 \mathrm{~Hz}, 1 \mathrm{H})$.

5-(Furan-2-yl)-2H-1,2,4-triazol-3-amine (3): Guanidine 2 $(53.6 \mathrm{mmol}, 9.0 \mathrm{~g})$ was stirred in a $1: 1$ mixture of $\mathrm{EtOAc} / \mathrm{H}_{2} \mathrm{O}$ $(400 \mathrm{~mL})$ for $3 \mathrm{~h}$. After extraction with EtOAc $(2 \times 150 \mathrm{~mL})$, the or- ganic layer was washed with $\mathrm{H}_{2} \mathrm{O}$ and brine $(2 \times 100 \mathrm{~mL}$ each) and dried over anhydrous $\mathrm{Na}_{2} \mathrm{SO}_{4}$. After removing the solvent, 4 was obtained as a white solid (6.51 g, two-step yield: $54 \%)$ : ${ }^{1} \mathrm{H}$ NMR (400 MHz, [D $\mathrm{D}_{6}$ ]DMSO): $\delta=12.08(\mathrm{brs}, 1 \mathrm{H}, \mathrm{NH}), 7.68(\mathrm{~s}, 1 \mathrm{H}), 6.67(\mathrm{~s}$, $1 \mathrm{H}), 6.54(\mathrm{~s}, 1 \mathrm{H}), 6.08 \mathrm{ppm}(\mathrm{s}, 2 \mathrm{H})$.

2-(Furan-2-yl)-5-(methylthio)-[1,2,4]triazolo[1,5-a][1,3,5]triazin-7amine (4): A mixture of amine $3(43.4 \mathrm{mmol}, 6.5 \mathrm{~g})$ and dimethyl $\mathrm{N}$-cyanodithio(imino)carbonate $(47.8 \mathrm{mmol}, 7.0 \mathrm{~g})$ was heated at $180^{\circ} \mathrm{C}$ in a stream of nitrogen for $4 \mathrm{~h}$, then cooled to room temperature to add $30 \mathrm{~mL}$ of a $\mathrm{CH}_{2} \mathrm{Cl}_{2} / \mathrm{CH}_{3} \mathrm{OH}$ (1:1) solution. The mixture was stirred at reflux for another $1.5 \mathrm{~h}$, followed by filtration. The solids were washed by the solution, and the solvent was removed under reduced pressure. The residue was purified by column chromatography, eluting with $\mathrm{CH}_{2} \mathrm{Cl}_{2}$ containing increasing amounts of EtOAc $(0-50 \%)$. This gave compound 4 as a paleyellow solid (3.2 g, yield: $30 \%):{ }^{1} \mathrm{H}$ NMR $\left(400 \mathrm{MHz}, \mathrm{CD}_{3} \mathrm{OD}\right): \delta=7.91$ (dd, $J=1.7,0.7 \mathrm{~Hz}, 1 \mathrm{H}), 7.12$ (dd, $J=3.4,0.7 \mathrm{~Hz}, 1 \mathrm{H}), 6.70$ (dd, $J=$ 3.4, $1.7 \mathrm{~Hz}, 1 \mathrm{H}), 2.55 \mathrm{ppm}(\mathrm{s}, 3 \mathrm{H})$.

2-(Furan-2-yl)-5-(methylsulfonyl)-[1,2,4]triazolo[1,5-a]-

[1,3,5]triazin-7-amine (5): A solution of $m C P B A(70 \%, 32.5 \mathrm{mmol}$, $8.0 \mathrm{~g})$ in $\mathrm{CH}_{2} \mathrm{Cl}_{2}(20 \mathrm{~mL})$ was added to a stirred, ice-cooled suspension of the sulfide $\left(\mathrm{R}=\right.$ MeSO) $(13.0 \mathrm{mmol}, 3.2 \mathrm{~g})$ in $\mathrm{CH}_{2} \mathrm{Cl}_{2}(50 \mathrm{~mL})$. The resulting solution was stirred overnight $\left(0^{\circ} \mathrm{C} \rightarrow\right.$ room temperature). The solvent was removed, and $\mathrm{EtOH}(70 \mathrm{~mL})$ was added to the residue. The solid was collected by filtration, washed with $\mathrm{EtOH}$, and dried in a vacuum oven to give a white solid $(\mathrm{R}=$ $\mathrm{MeSO}_{2}$ ) (yield: $3.2 \mathrm{~g}, 88 \%$ ): ${ }^{1} \mathrm{H}$ NMR $\left(400 \mathrm{MHz},\left[\mathrm{D}_{6}\right] \mathrm{DMSO}\right): \delta=9.81$ and $9.48\left(2 \times \mathrm{s}\right.$ due to dimer formation, $\left.{ }^{[8 c]} 2 \mathrm{H}, \mathrm{NH}_{2}\right), 7.98(\mathrm{dd}, J=$ $1.2,0.8 \mathrm{~Hz}, 1 \mathrm{H}), 7.34(\mathrm{dd}, J=2.4,0.8 \mathrm{~Hz}, 1 \mathrm{H}), 6.73(\mathrm{dd}, J=2.4$, $1.2 \mathrm{~Hz}, 1 \mathrm{H}), 3.35 \mathrm{ppm}(\mathrm{s}, 3 \mathrm{H})$.

1-(2,4-Dichlophenyl)piperazine (9v): A mixture of 6 (16.7 $\mathrm{mmol}$, $2.0 \mathrm{~mL}$ ) and piperazine $(83.6 \mathrm{mmol}, 7.2 \mathrm{~g})$ in $10 \mathrm{~mL}$ of $\mathrm{N}, \mathrm{N}$-dimethylacetamide was heated in the microwave at $165^{\circ} \mathrm{C}$ for $6.5 \mathrm{~h}$, after which 6 was consumed, as shown by TLC. $\mathrm{H}_{2} \mathrm{O}$ and $\mathrm{CH}_{2} \mathrm{Cl}_{2}$ were added, and the $\mathrm{pH}$ value was adjusted to 1 with $1 \mathrm{M} \mathrm{HCl}_{\text {(aq). }}$. The aqueous layer was washed three times with $\mathrm{CH}_{2} \mathrm{Cl}_{2}$ and subsequently brought to $\mathrm{pH} 12$ with $5 \mathrm{M} \mathrm{NaOH}_{(\mathrm{aq})}$. After extraction of the basified aqueous layer with $\mathrm{CH}_{2} \mathrm{Cl}_{2}$, the combined organic layers were washed four times with $\mathrm{H}_{2} \mathrm{O}$, dried over $\mathrm{MgSO}_{4}$, and concentrated in vacuo to yield $9 \mathrm{v}$ as a yellow oil (yield: $2.4 \mathrm{~g}, 61 \%$ ): ${ }^{1} \mathrm{H}$ NMR $\left(400 \mathrm{MHz}, \mathrm{CDCl}_{3}\right): \delta=7.36(\mathrm{~d}, J=2.4 \mathrm{~Hz}, 1 \mathrm{H}), 7.19$ (dd, $J=$ $8.8,2.4 \mathrm{~Hz}, 1 \mathrm{H}), 6.95(\mathrm{~d}, J=8.4 \mathrm{~Hz}, 1 \mathrm{H}), 3.06-3.02\left(\mathrm{~m}, 5 \mathrm{H}, 2 \times \mathrm{CH}_{2}\right.$ and $\mathrm{NH}), 2.99-2.96 \mathrm{ppm}(\mathrm{m}, 4 \mathrm{H})$.

1-(2-Fluoro-4-methoxyphenyl)piperazine hydrochloride (9w): A mixture of bis(2-chloroethyl)amine hydrochloride $(9.59 \mathrm{mmol}, 1.7 \mathrm{~g})$ (7) and 1-BuOH $(20 \mathrm{~mL})$ was treated slowly with 2-fluoro-4-methoxybenzenamine $(9.14 \mathrm{mmol}, 1.3 \mathrm{~g})$ at room temperature. After the addition, the mixture was stirred at reflux for $48 \mathrm{~h}$ and then cooled. The solid was filtered and rinsed with $\mathrm{CH}_{3} \mathrm{OH}$ and $\mathrm{Et}_{2} \mathrm{O}$ to give $9 \mathrm{w}$ as a white solid (yield: $660 \mathrm{mg}, 29 \%)$ : ${ }^{1} \mathrm{H}$ NMR $(400 \mathrm{MHz}$, $\left.\mathrm{CDCl}_{3}\right): \delta=9.21(\mathrm{brs}, 2 \mathrm{H}, \mathrm{NH}$, and $\mathrm{HCl}), 7.07-7.02(\mathrm{~m}, 1 \mathrm{H}), 6.86-$ $6.83(\mathrm{~m}, 1 \mathrm{H}), 6.74-6.71(\mathrm{~m}, 1 \mathrm{H}), 3.72(\mathrm{~s}, 3 \mathrm{H}), 3.28-3.20(\mathrm{~m}, 4 \mathrm{H})$, $3.14-3.10 \mathrm{ppm}(\mathrm{m}, 4 \mathrm{H})$.

1-(2,4-Difluorophenyl)piperazine) (9x): A mixture of piperazine (24.9 mmol, $2.14 \mathrm{~g})$, 1-bromo-2,4-difluorobenzene (8) $(4.1 \mathrm{mmol}$, $0.8 \mathrm{~g}), t$ BuONa $(5.8 \mathrm{mmol}, 0.56 \mathrm{~g}), \operatorname{BINAP}(0.25 \mathrm{mmol}, 0.16 \mathrm{~g})$, and $\mathrm{Pd}_{2}(\mathrm{dba})_{3}(0.083 \mathrm{mmol}, 0.048 \mathrm{~g})$ in dry toluene was heated at $110^{\circ} \mathrm{C}$ under a nitrogen atmosphere for $24 \mathrm{~h}$. The mixture was filtered over Celite and rinsed with $\mathrm{CH}_{2} \mathrm{Cl}_{2}$. The solution was washed with $\mathrm{H}_{2} \mathrm{O}$ and brine $\left(2 \times 10 \mathrm{~mL}\right.$ each), dried over $\mathrm{Na}_{2} \mathrm{SO}_{4}$, and the solvent was evaporated in vacuo. The residue was purified by silica 
gel via $\mathrm{CH}_{2} \mathrm{Cl}_{2} / \mathrm{CH}_{3} \mathrm{OH}$ (10:1) to give compound $9 \mathbf{x}$ as a pale-yellow oil (yield: $337 \mathrm{mg}, 42 \%)$ : ${ }^{1} \mathrm{H}$ NMR $\left(400 \mathrm{MHz}, \mathrm{CDCl}_{3}\right): \delta=6.91-6.87$ $(\mathrm{m}, 1 \mathrm{H}), 6.83-6.78(\mathrm{~m}, 2 \mathrm{H}), 3.06(\mathrm{t}, J=3.6 \mathrm{~Hz}, 4 \mathrm{H}), 3.00-2.97(\mathrm{~m}$, $4 \mathrm{H}), 1.80 \mathrm{ppm}(\mathrm{s}, 1 \mathrm{H}, \mathrm{NH})$.

General procedure for the preparation of compounds $10 \mathrm{a}-\mathrm{d}$ and $10 \mathrm{i}-\mathbf{x}$ : A mixture of the appropriate phthalimide-protected alkyl bromide $(7.5 \mathrm{mmol})$, piperazine derivative $(5 \mathrm{mmol})$ and $\mathrm{K}_{2} \mathrm{CO}_{3}$ $(10 \mathrm{mmol})$ in DMF $(5 \mathrm{~mL})$ was stirred at $70^{\circ} \mathrm{C}$ overnight. The reaction mixture was cooled, washed with $\mathrm{H}_{2} \mathrm{O}(5 \mathrm{~mL})$, and extracted with EtOAc $(3 \times 10 \mathrm{~mL}$ each). The organic phase was then combined, dried over $\mathrm{Na}_{2} \mathrm{SO}_{4}$, and evaporated in vacuo to give the crude product, which was recrystallized from $\mathrm{EtOH}$ and/or $\mathrm{CH}_{3} \mathrm{OH}$ or purified by chromatography (petroleum ether/EtOAc).

2-(2-(4-Phenylpiperazin-1-yl)ethyl)isoindoline-1,3-dione $\quad(10 \mathrm{a})$ : Compound 10 a was obtained as a pale-yellow solid after column chromatography with petroleum ether/EtOAc $(5: 1-1: 1)$ (yield: $1.5 \mathrm{~g}, 43 \%):{ }^{1} \mathrm{H}$ NMR $\left(400 \mathrm{MHz}, \mathrm{CDCl}_{3}\right): \delta=7.86-7.80(\mathrm{~m}, 4 \mathrm{H}), 7.25-$ $7.24(\mathrm{~m}, 2 \mathrm{H}), 6.91-6.88(\mathrm{~m}, 2 \mathrm{H}), 6.80(\mathrm{t}, J=8.1 \mathrm{~Hz}, 1 \mathrm{H}), 3.87(\mathrm{t}, J=$ $6.3 \mathrm{~Hz}, 2 \mathrm{H}), 3.15-3.12(\mathrm{~m}, 4 \mathrm{H}), 2.72-2.68 \mathrm{ppm}(\mathrm{m}, 6 \mathrm{H})$.

General procedure for preparation of compounds $11 \mathrm{a}-\mathrm{d}$ and $11 \mathbf{i}-\mathbf{x}$ : An excess of hydrazine hydrate was added (1-5 mL) to a solution of isoindoline-1,3-dione $(3 \mathrm{mmol})$ in $\mathrm{EtOH}(25 \mathrm{~mL})$, and the mixture was stirred at $70^{\circ} \mathrm{C}$ overnight. The solvent was removed in vacuo, and EtOAc was added to the residue. The solids were filtered, dried over $\mathrm{Na}_{2} \mathrm{SO}_{4}$, and the solvent was evaporated in vacuo to give the crude product as a pale-yellow oil or solid. The crude product was used in the next step without further purification.

General procedure for preparation of compounds $12 \mathrm{a}-\mathrm{x}$ : A mixture of the respective amine $(0.75 \mathrm{mmol})$, the sulfone/sulfoxide mixture (5) $(0.50 \mathrm{mmol})$, and $\mathrm{Et}_{3} \mathrm{~N}(1.0 \mathrm{mmol})$ was dissolved in $\mathrm{CH}_{3} \mathrm{CN}$ and stirred at reflux overnight. After removing the solvent in vacuo, EtOAc was added, and the organic phase was washed with $\mathrm{H}_{2} \mathrm{O}$ and brine $\left(2 \times 10 \mathrm{~mL}\right.$ each), dried over $\mathrm{Na}_{2} \mathrm{SO}_{4}$, and evaporated. The residue was purified by column chromatography using silica gel and EtOAc or EtOAc/ $/ \mathrm{CH}_{3} \mathrm{OH}$ to afford a white or off-white solid.

2-(Furan-2-yl)-N5-(2-(4-phenylpiperazin-1-yl)ethyl)-[1,2,4]triazolo$[1,5-a][1,3,5]$ triazine-5,7-diamine (12a): Eluting with EtOAc/ $\mathrm{CH}_{3} \mathrm{OH}(10: 1)$ afforded the title compound as a white powder (yield: $55 \mathrm{mg}, 14 \%):{ }^{1} \mathrm{H}$ NMR ( $\left.400 \mathrm{MHz}, \mathrm{MeOD}\right): \delta=7.68(\mathrm{~s}, 1 \mathrm{H})$, $7.22(\mathrm{t}, J=8.4 \mathrm{~Hz}, 2 \mathrm{H}), 7.12(\mathrm{~d}, J=3.2 \mathrm{~Hz}, 1 \mathrm{H}), 6.96(\mathrm{~d}, J=8.4 \mathrm{~Hz}$ $2 \mathrm{H}), 6.84-6.81(\mathrm{~m}, 1 \mathrm{H}), 6.60(\mathrm{~d}, J=1.6 \mathrm{~Hz}, 1 \mathrm{H}), 3.61-3.60(\mathrm{~m}, 2 \mathrm{H})$, $3.20(\mathrm{t}, J=4.8 \mathrm{~Hz}, 4 \mathrm{H}), 2.72(\mathrm{t}, J=4.8 \mathrm{~Hz}, 4 \mathrm{H}), 2.68-2.67 \mathrm{ppm}(\mathrm{m}$, $2 \mathrm{H}) .{ }^{13} \mathrm{C}$ NMR $\left(101 \mathrm{MHz},\left[\mathrm{D}_{6}\right.\right.$ ]DMSO): $\delta=161.6,159.7,156.3,151.5$, 150.5, 146.7, 145.1, 129.4, 119.2, 115.8, 112.4, 112.1, 57.1, 53.2, 48.7, $38.5 \mathrm{ppm}$. HRMS (ESI) $\mathrm{m} / \mathrm{z}[\mathrm{M}+\mathrm{H}]^{+}$calcd for $\mathrm{C}_{20} \mathrm{H}_{24} \mathrm{~N}_{9} \mathrm{O}^{+}: 406.2026$, found: 406.2092 ; HPLC: $t_{\mathrm{R}}=11.96 \mathrm{~min}$, purity $=96.7 \%$.

\section{Pharmacological characterization}

Materials: $\left[{ }^{3} \mathrm{H}\right] \mathrm{ZM} 241385$ (specific activity $50 \mathrm{Cimmol}^{-1}$ ) and $\left[{ }^{3} \mathrm{H}\right] 1,3$-dipropyl-8-cyclopentyl-xanthine $\left({ }^{3} \mathrm{H}\right] \mathrm{DPCPX}$, specific activity $116.7 \mathrm{Ci} \mathrm{mmol}^{-1}$ ) were purchased from ARC Inc. (St. Louis, USA). Unlabeled ZM241385 was a gift from Dr. S. M. Poucher (AstraZeneca, Macclesfield, UK). CGS21680 was a gift from Dr. R. A. Lovell (CibaGeigy, Summit, NJ). NECA (5'-N-ethylcarboxamidoadenosine) and DPCPX were purchased from Sigma-Aldrich (Steinheim, Germany). Adenosine deaminase (ADA) was purchased from Boehringer Mannheim (Mannheim, Germany). Bicinchoninic acid (BCA) and BCA protein assay reagent were obtained from Pierce Chemical Company (Rockford, IL, USA). Human embryonic kidney cells stably expressing the $h A_{2 A} R\left(H E K 293 h A_{2 A} R\right)$ were kindly provided by Dr. J. Wang (Biogen/IDEC, Cambridge, MA). Chinese hamster ovary cells stably expressing the $h A_{1} R\left(C_{H O h A_{1}} R\right)$ were kindly provided by Prof. Steve Hill (University of Nottingham, UK). All other chemicals were of analytical grade and obtained from standard commercial sources.

Cell culture and membrane preparation: Cell culture and membrane preparation were performed as reported previously. ${ }^{[15 b, 21]}$

Radioligand displacement assay: Radioligand displacement from the $h A_{1} R$ and $h A_{2 A} R$ was determined using the displacement assay as described previously. ${ }^{[15 b, 21]}$

Radioligand competition association assay: The binding kinetics of unlabeled $A_{2 A} R$ ligands were determined at $4{ }^{\circ} \mathrm{C}$ using the competition association assay as described previously. ${ }^{[15 b]}$

cAMP assay: HEK293 $\mathrm{hA}_{2 \mathrm{~A}} \mathrm{R}$ cells were cultured as a monolayer on $10 \mathrm{~cm} \varnothing$ culture plates to $80 \%-90 \%$ confluency. Cells were harvested and centrifuged two times at $200 \times \mathrm{g}$ for $5 \mathrm{~min}$. The amount of CAMP produced was determined with the LANCE ultra CAMP 384 kit (PerkinElmer, Groningen, Netherlands). In general, 1000 cells per well were seeded on 384-well plates and incubated at room temperature $\left(22-25^{\circ} \mathrm{C}\right)$. CAMP was generated in the stimulation buffer [N-2-hydroxyethylpiperazine- $N$ '-ethanesulfonic acid (HEPES), $5 \mathrm{~mm}$; $0.1 \%(w / v)$ BSA; cilostamide, $50 \mu \mathrm{M}$; rolipram, $50 \mu \mathrm{M}$; adenosine deaminase (ADA), $0.8 \mathrm{IU} \mathrm{mL}^{-1}$ ] Concentration-effect curves for $12 \mathrm{x}$ and $12 \mathrm{c}$ were obtained by adding HEK293 $\mathrm{hA}_{2 \mathrm{~A}} \mathrm{R}$ cells to a mixture of antagonist (12x or $12 \mathrm{c}$ ) and $100 \mathrm{nM}$ NECA (prepared in the stimulation buffer) for a $30 \mathrm{~min}$ co-incubation. For assessment of either surmountable or insurmountable behavior, the antagonists (12x and $12 \mathrm{c}$ ) were pre-incubated for $30 \mathrm{~min}$ or co-incubated with the agonist NECA at concentrations ranging from $100 \mu \mathrm{M}$ to $0.1 \mathrm{nM}$ for a duration of $30 \mathrm{~min}$, with antagonist concentrations of $0.3-$, one-, two- and tenfold their respective $K_{\mathrm{i}}$ values. The incubation was stopped by adding detection mix and antibody solution, according to the instructions of the manufacturer. The generated fluorescence intensity was quantified on an EnVision Multilabel Reader (PerkinElmer, Groningen, Netherlands). The resulting data were normalized according to the maximal response produced by $100 \mu \mathrm{M}$ NECA. The shift in agonist $\mathrm{EC}_{50}$ was determined to perform Schild analyses.

Data analysis: All experimental data was analyzed using GraphPad Prism 5.0 (GraphPad Software Inc., San Diego, CA). $K_{D}$ and $B_{\max }$ values of $\left[{ }^{3} \mathrm{H}\right] Z M 241385$ at $h A_{2 A} R$ membranes were obtained from Guo et al. ${ }^{[15 b]} I C_{50}$ values obtained from competition displacement binding data were converted into $K_{\mathrm{i}}$ values using the Cheng-Prusoff equation. ${ }^{[22]}$ Association and dissociation rates for unlabeled ligands were calculated by fitting the data in the competition association model using kinetics of competitive binding: $:^{[11]}$

$$
\begin{aligned}
& K_{\mathrm{A}}=k_{1}[L]+K_{2} \\
& K_{\mathrm{B}}=k_{3}[L]+K_{4} \\
& S=\sqrt{\left[\left(K_{\mathrm{A}}-K_{\mathrm{B}}\right)^{2}+4 \cdot k_{1} \cdot k_{3} \cdot L \cdot l\right]} \\
& K_{\mathrm{F}}=0.5\left(K_{\mathrm{A}}+K_{\mathrm{B}}+S\right) \\
& K_{\mathrm{S}}=0.5\left(K_{\mathrm{A}}+K_{\mathrm{B}}-S\right) \\
& Q=B_{\max } \cdot K_{1} \cdot L \cdot\left(K_{\mathrm{F}}-K_{\mathrm{S}}\right)^{-1} \\
& Y=Q \cdot\left[K_{4} \cdot\left(K_{\mathrm{F}}-K_{\mathrm{S}}\right) \cdot K_{\mathrm{F}}^{-1} \cdot K_{\mathrm{S}}{ }^{-1}+\left(k_{4}-K_{\mathrm{F}}\right) \cdot K_{\mathrm{F}}^{-1}\right. \\
& \left.\cdot e^{-K_{\mathrm{F}} \cdot X}-\left(K_{4}-K_{\mathrm{S}}\right) \cdot K_{\mathrm{S}}^{-1} \cdot e^{-K_{\mathrm{S}} \cdot X}\right]
\end{aligned}
$$


Where $X$ is the time $(\min ), Y$ is the specific $\left[{ }^{3} \mathrm{H}\right] \mathrm{ZM} 241385$ binding (DPM), $k_{1}$ and $k_{2}$ are the $k_{\text {on }}\left(\mathrm{nM}^{-1} \cdot \mathrm{min}^{-1}\right)$ and $k_{\text {off }}\left(\mathrm{min}^{-1}\right)$ values of $\left[{ }^{3} \mathrm{H}\right] \mathrm{ZM} 241385$ obtained from Guo et al.,${ }^{[15 b]} L$ is the concentration of $\left[^{3} \mathrm{H}\right] Z \mathrm{ZM} 241385$ used (nM), $B_{\max }$ is the total binding (DPM), and $I$ is the concentration of unlabeled ligand (nM). Fixing these parameters allows the following parameters to be calculated: $k_{3}$, which is the $k_{\text {on }}$ value $\left(\mathrm{nM}^{-1} \cdot \mathrm{min}^{-1}\right)$ of the unlabeled ligand, and $k_{4}$, which is the $k_{\text {off }}$ value $\left(\mathrm{min}^{-1}\right)$ of the unlabeled ligand. Molecular property descriptors $\left(M_{r}, \log P, M S A, p K_{a}\right)$ of the substituted $C_{2}$-phenylpiperazine were calculated using MarinSketch 5.11 (ChemAxon, Hungary). (Multiple) Linear regression analysis was done using Microsoft Excel 2003.

\section{Acknowledgements}

The authors thank Dr. Ron Dror and Dr. Albert Pan (D. E. Shaw Research, USA) for fruitful discussions, and Dr. Julien Louvel and Mr. Maris Vilums for helpful comments on the manuscript. This project was supported financially by the Innovational Research Incentive Scheme of the Netherlands Research Organization (NWO; VENI-Grant 11188 to L.H.).

Keywords: binding kinetics - G protein-coupled receptors antagonism - structure-activity relationships • structurekinetics relationships

[1] a) R. Zhang, F. Monsma, Expert Opin. Drug Discovery 2010, 5, 1023 1029; b) R. A. Copeland, D. L. Pompliano, T. D. Meek, Nat. Rev. Drug Discovery 2006, 5, 730-739; c) D. C. Swinney, Nat. Rev. Drug Discovery 2004, 3, $801-808$; d) D. C. Swinney, Lett. Drug Des. Discovery 2006, 3, 569-574; e) S. Núnez, J. Venhorst, C. G. Kruse, Drug Discovery Today 2012, 17, 10-22.

[2] a) E. M. Rosethorne, R. J. Turner, R. A. Fairhurst, S. J. Charlton, NaunynSchmiedeberg's Arch. Pharmacol. 2010, 382, 255-263; b) C. C. Govern M. K. Paczosa, A. K. Chakraborty, E. S. Huseby, Proc. Natl. Acad. Sci. USA 2010, 107, 8724-8729; c) J. Foote, H. N. Eisen, Proc. Natl. Acad. Sci. USA 1995, 92, 1254-1256; d) G. Schreiber, Curr. Opin. Struct. Biol. 2002, 12, 41-47; e) T. Selzer, S. Albeck, G. Schreiber, Nat. Struct. Biol. 2000, 7 537-541; f) D. A. Sykes, M. R. Dowling, J. Leighton-Davies, T. C. Kent, E. Renard, A. Trifilieff, S. J. Charlton, J. Pharmacol. Exp. Ther. 2012, 343, $520-528$.

[3] B. B. Fredholm, A. P. IJzerman, K. A. Jacobson, J. Linden, C. E. Müller, Pharmacol. Rev. 2011, 63, 1-34.

[4] K. A. Jacobson, Z. G. Gao, Nat. Rev. Drug Discovery 2006, 5, 247-264.

[5] a) B. C. Shook, P. F. Jackson, ACS Chem. Neurosci. 2011, 2, 555-567; b) C. E. Müller, K. A. Jacobson, Biochim. Biophys. Acta Biomembr. 2011 1808, 1290-1308; c) U. Shah, R. Hodgson, Curr. Opin. Drug Discov. Devel. 2010, 13, 466-480.

[6] a) S. M. Poucher, J. R. Keddie, P. Singh, S. M. Stoggall, P. W. Caulkett, G. Jones, M. G. Coll, Br. J. Pharmacol. 1995, 115, 1096-1102; b) P. W. R Caulkett, G. Jones, M. G. Collis, S. M. Poucher, (Imperial Chemical Industry PLC, London, UK), European Patent No. EP 459702, 1991.

[7] a) C. B. Vu, D. Pan, B. Peng, G. Kumaravel, G. Smits, X. Jin, D. Phadke, T. Engber, C. Huang, J. Reilly, S. Tam, D. Grant, G. Hetu, R. C. Petter, J. Med. Chem. 2005, 48, 2009-2018; b) C. B. Vu, B. Peng, G. Kumaravel, G.
Smits, X. Jin, D. Phadke, T. Engber, C. Huang, J. Reilly, S. Tam, D. Grant G. Hetu, L. Chen, J. Zhang, R. C. Petter, J. Med. Chem. 2004, 47, $4291-$ 4299; c) C. B. Vu, P. Shields, B. Peng, G. Kumaravel, X. Jin, D. Phadke, J. Wang, T. Engber, E. Ayyub, R. C. Petter, Bioorg. Med. Chem. Lett. 2004, $14,4835-4838$

[8] a) A. V. Dolzhenko, A. V. Dolzhenko, W. K. Chui, Tetrahedron 2007, 63, 12888-12895; b) A. V. Dolzhenko, G. Pastorin, A. V. Dolzhenko, W. K. Chui, Tetrahedron Lett. 2009, 50, 2124-2128; c) M. Jörg, M. Agostino, E. Yuriev, F. S. Mak, N. D. Miller, J. M. White, P. J. Scammells, B. Capuano, Struct. Chem. 2013, 24, 1241-1251; d) M. Jörg, J. Shonberg, F. S. Mak, N. D. Miller, E. Yuriev, P. J. Scammells, B. Capuano, Bioorg. Med. Chem Lett. 2013, 23, 3427-3433.

[9] P. W. R. Caulkett, G. Jones, M. McPartlin, N. D. Renshaw, S. K. Stewart, B. Wright, J. Chem. Soc. Perkin Trans. 1 1995, 801-808.

[10] a) R. E. Tenbrink (Pharmacia \& Upjohn Company, MI, USA), US Patent No. US5912246, 1999; b) G. E. Martin, R. J. Elgin, Jr., J. R. Mathiasen, C. B. Davis, J. M. Kesslick, W. J. Baldy, R. P. Shank, D. L. DiStefano, C. L. Fedde, M. K. Scott, J. Med. Chem. 1989, 32, 1052-1056; c) S. Morita, K. Kitano J. Matsubara, T. Ohtani, Y. Kawano, K. Otsubo, M. Uchida, Tetrahedron 1998, 54, $4811-4818$

[11] H. J. Motulsky, L. C. Mahan, Mol. Pharmacol. 1984, 25, 1 -9.

[12] a) G. Vauquelin, I. Van Liefde, P. Vanderheyden, Trends Pharmacol. Sci. 2002, 23, 514-518; b) T. Kenakin, S. Jenkinson, C. Watson, J. Pharmacol. Exp. Ther. 2006, 319, 710-723; c) G. Vauquelin, A. Szczuka, Neurochem. Int. 2007, 51, 254-260.

[13] a) D. A. Sykes, M. R. Dowling, S. J. Charlton, Mol. Pharmacol. 2009, 76, $543-551$; b) D. Guo, T. Mulder-Krieger, A. P. IJzerman, L. H. Heitman, Br. J. Pharmacol. 2012, 166, 1846-1859.

[14] a) S. J. Mantell, P. T. Stephenson, S. M. Monaghan, G. N. Maw, M. A. Trevethick, M. Yeadon, R. F. Keir, D. K. Walker, R. M. Jones, M. D. Selby, D. V. Batchelor, S. Rozze, H. Chavaroche, T. J. Hobson, P. G. Dodd, A. Lemaitre K. N. Wright, E. F. Stuart, Bioorg. Med. Chem. Lett. 2008, 18, 1284-1287; b) S. J. Mantell, P. T. Stephenson, S. M. Monaghan, G. N. Maw, M. A. Trevethick, M. Yeadon, D. K. Walker, M. D. Selby, D. V. Batchelor, S. Rozze, H. Chavaroche, A. Lemaitre, K. N. Wright, L. Whitlock, E. F. Stuart, P. A. Wright, F. Macintyre, Bioorg. Med. Chem. Lett. 2009, 19, 4471-4475.

[15] K. Andersson, R. Karlsson, S. Lofas, G. Franklin, M. D. Hamalainen, Expert Opin. Drug Discovery 2006, 1, 439-446.

[16] J. Gabrielsson, H. Dolgos, P. G. Gillberg, U. Bredberg, B. Benthem, G. Duker, Drug Discovery Today 2009, 14, 358-372.

[17] W. Liu, E. Chun, A. A. Thompson, P. Chubukov, F. Xu, V. Katritch, G. W. Han, C. B. Roth, L. H. Heitman, A. P. IJzerman, V. Cherezov, R. C. Stevens, Science 2012, 337, 232-236.

[18] F. Xu, H. Wu, V. Katritch, G. W. Han, K. A. Jacobson, Z. G. Gao, V. Cherezov, R. C. Stevens, Science 2011, 332, $322-327$.

[19] R. O. Dror, A. C. Pan, D. H. Arlow, D. W. Borhani, P. Maragakis, Y. Shan, H. Xu, D. E. Shaw, Proc. Natl. Acad. Sci. USA 2011, 108, 13118-13123.

[20] A. C. Kruse, J. Hu, A. C. Pan, D. H. Arlow, D. M. Rosenbaum, E. Rosemond, H. F. Green, T. Liu, P. S. Chae, R. O. Dror, D. E. Shaw, W. I. Weis, J. Wess, B. K. Kobilka, Nature 2012, 482, 552-556.

[21] D. Guo, E. J. van Dorp, T. Mulder-Krieger, J. P. van Veldhoven, J. Brussee, A. P. IJzerman, L. H. Heitman, J. Biomol. Screening 2013, 18, 309-320.

[22] Y. Cheng, W. H. Prusoff, Biochem. Pharmacol. 1973, 22, 3099-3108.

[23] E. Ongini, S. Dionisotti, S. Gessi, E. Irenius, B. B. Fredholm, NaunynSchmiedeberg's Arch. Pharmacol. 1999, 359, 7-10.

Received: November 21, 2013

Revised: January 27, 2014

Published online on March 3, 2014 